\title{
Behavior of mother to visit posyandu in magetan regency, indonesia
}

\author{
Agung Suharto ${ }^{1 *}$ (D) Oedojo Soedirham ${ }^{2}$ D , Suparji Suparji ${ }^{1} \mathbb{D}$, Feftin Hendriyani ${ }^{1}$ (D) \\ ${ }^{1}$ Department of Midwifery, Health Polytechnic, Ministry of Health Surabaya, Surabaya, Indonesia; ${ }^{2}$ Department of Public Health, \\ Faculty of Public Health, Universitas Airlangga, Surabaya, Indonesia
}

Edited by: Sasho Stolesk Citation: Suharto A, Soedirham O, Suparji S, Hendriyani . Behavior of Mother to Visit Posyandu in Magetan Sci. 2021 Dec 24; 9(E):1590-1595. https://doi.org/10.3889/ oamjms.2021.6748

Keywords: Precede-proceed model; Social capital Posyandu (integrated service post) *Correspondence: Agung Suharto, Department of dwifery, Politeknik Kesehatan Kementerian Kesehatan urabaya, Jl. Pucang Jajar Tengah No. 56 Surabaya, Indonesia. E-mail: agungsuharto14@gmail.com Revised: 16 - Aug-202 Accepted: 16-Dec-2021 Copyright: $\odot 2021$ Agung Suharto, Oedojo Soedirham Suparji Supari, Feftin Hendriyan Funding: This research did not receive any financial Competing Interests: The authors have declared that no competing interests exis Open Access: This is an open-access article distributed under the terms of the Creative Commons Attribution-

\begin{abstract}
BACKGROUND: The purpose of this study was to develop a model of precede-proceed and social capital influence the improvement of maternal behavior visit to posyandu (the integrated service post).

MATERIALS AND METHODS: This study was create model of behavior with cross sectional design. The population was mothers in Magetan and the sample size was 400 , selected using simple random sampling. Exogenous variable was social capital, while endogenous variables were predisposing factors, reinforcing factors, enabling factors, and behavior. Statistical analysis was Confirmatory Factor Analysis and Structural Equation Modeling with the program of Amos 18. Phase 2 was non-equivalent control group pretest-posttest. The independent variable was behavioral models, while dependent variable was the behavior of the mother visited posyandu. Statistical analysis was t-test.

RESULTS AND ANALYSIS: Intervention precede-proceed model of social capital influence the improvement of maternal behavior to visit posyandu $(p=0.000)$.

CONCLUSION: The intervention precede-proceed model and social capital influence the improvement of materna behavior to visit posyandu.
\end{abstract}

\section{Introduction}

Posyandu (Integrated Service Post) integrates various activities aimed at improving maternal and child health and nutritional status of the community with community participation through health cadres. Posyandu held at least five priority programs, namely maternal and child health, family planning, nutrition improvement, immunization, and prevention of diarrhea. To monitor the development of Integrated service post then grouped in four levels: Posyandu Pratama (lowest), Posyandu Madya, Posyandu Purnama and Posyandu Mandiri (highest). Community empowerment is an effort to enable the community so that they are able to recognize and solve problems. Various communitybased health efforts have been developed in Indonesia such as Integrated Service Posts (Posyandu), Village Maternity Boarding Schools (Polindes), Village Health Posts (Poskesdes), POD village medicine posts, health funds, etc., but their utilization is still lacking [1].

The number of posyandu in Magetan regency in 2015 is 920 units consisting of 31 Posyandu Pratama (3.37\%), 237 Posyandu Madya (29.67\%), 583 Posyandu Purnama (63.37\%) and 33 Posyandu andiri (3.59\%). The number of Posyandu cadres in Magetan regency is 230 people, while the number of active cadres is 223 . Community participation in nutrition improvement for under five can be shown from the indicator of the number of children under five divided by the number of children was $41.42-100 \%$ The lowest number of visits was at the Parang Community Health Center in 2010 (41.42\%) and the highest was Taji Community Health Center (100\%). Target of toddler visits to Posyandu in Magetan regency in 2015 is $84 \%$ [2].

That the reason the mother did not come to posyandu mostly because immunization is complete so no need to Integrated service post as much as $40 \%$ and small part because work so do not have time to bring their child to Integrated service post as much as $10 \%$. According to the precede-proceed model is a cost benefit evaluation framework that can help health program planners, policy makers, and other evaluators analyze situations and programs of efficient design health. The result of the research on social capital exploration which influenced to the mother behavior of the toddler visited the posyandu in Magetan Regency, proved that the factors that significantly influence the behavior of the mother toddler visit the posyandu park are participation, proactive, partenships and reciprocity. While the factor of value and norm, diversity, flavor have and trust does not significantly influence the behavior of mother to visit posyandu in Magetan Regency [3].

From the above description, the authors examine the development of precede-proceed model 
and social capital to improve the behavior of mothers visiting Posyandu in Magetan District.

\section{Materials and Methods}

\section{Phase 1}

Developing behavioral model of mother visiting posyandu using analytical survey technique with cross-sectional design a study to study the dynamics of the correlation between risk factors and effects, and with an approach, observation or data collection at a certain point in time (point time approach)., to construct model of mother behavior of toddler by doing blended two model that is precede-proceed model and social capital [4]. The research population was mother who has toddlers in community health center area in Magetan Regency in 2016 as many as 36,781 toddlers with sample size of 400 people. The sample criteria used are: Mothers who have children under five, are willing to be research respondents. The number of samples is calculated based on the rule of thumb, because there are 40 parameters, the number of samples is 400 [5]. Exogenous variable in this research was Social Capital, while endogenous variables were predisposing factors, reinforcing factors, enabling factors and the behavior of toddler mothers visit posyandu. The conceptual basis for placing the variables referred to in the model as exogenous variables (Social Capital), endogenous variables (predisposing factors, reinforcing factors, and supporting factors) the behavior of mothers visiting posyandu is using a combination of precede proceed theory and social capital and this model can be applied in all Posyandu in Indonesia, with various situations and conditions as well as geography and health services. The data were collected using questionnaire. After the data collected performed processing and data analysis, according to the purpose of research and then set up a behavior model derived from factors that influence significantly. Data processing research as follows: editing, coding, tabulating, and cleaning. Data analysis includes: (1) Descriptive analysis; (2) To examine the effect of exogenous variables include social capital on endogenous variables including predisposing factors, reinforcing factors, enabling factors, and behavior/behavior of mothers visiting posyandu using Confirmatory Factor Analysis and Structural Equation Modeling (SEM) with Amos 18 program [6].

\section{Phase II}

Aimed to prove the model using non equivalent control group pretest-postest design. In this second phase of research, the author uses the development of a precede proceeds and social capital model of significant factors that have been designed in the form of a module for health promotion in the intervention group and the control group. The research location was Posyandu Melati, 1, 2, 3 and 4, Milangasri at Village, Panekan Subdistrict, Magetan District. This research conducted in August to September 2016. Population in research was mother of children in posyandu as many as 150 people. The sample size was 100 people, selected using simple random sampling. The sample selected in stage 2 is different from the sample tested in the previous stage. The sample in this second stage has the following criteria: Mothers who have toddlers, live in the milangasri village area and are willing to be research respondents [4]. The independent variable was behavioral model with blended two model that was social capital and precede proceed model. The dependent variable was the behavior of the mother visiting the posyandu. Data analysis was done by: (1) descriptive analysis; (2) to analyze the influence of intervention of precede proceed model and social capital on the behavior of mother to visit posyandu using t-test [7].

\section{Results}

From SEM results will be obtained significant or insignificant factors. The influence of this significant factor that will be used as the basis for modeling will be done in the form of module intervention to the respondent.

From Figure 1, The results of the final SEM test on the causality relationship of research factors obtained 5 valid and significant relationships including social capital influencing reinforcing factors, reinforcing factors affecting predisposing factors, reinforcing factors influencing behavior, and predisposing factors influencing behavior. To assess the validation of the overall model prediction, it can be seen with the Goodness of Fit value which includes: Chi-square, Probability, RMSEA, and goodness of fit index (GFI). From the results of the SEM analysis obtained the value of Chi-square (CMIN): 294.7918; Probability value: 0.000; RMSEA: 0.0990 and GFI value: 0.8993 . From this value, the behavioral model can be declared fit and significant.

Table 1: Regression weights test of SEM

\begin{tabular}{|c|c|c|c|c|c|c|}
\hline \multicolumn{3}{|c|}{ The relationship of indicator causality } & \multirow{2}{*}{$\begin{array}{l}\text { Estimate } \\
0.4108\end{array}$} & \multirow{2}{*}{$\begin{array}{l}\text { S.E. } \\
0.0408\end{array}$} & \multirow{2}{*}{$\begin{array}{l}\text { C.R. } \\
10.0772\end{array}$} & \multirow{2}{*}{$\begin{array}{l}\text { Information } \\
\text { Valid and } \\
\text { significant }\end{array}$} \\
\hline Social Capital & $\rightarrow$ & $\begin{array}{l}\text { Reinforcing } \\
\text { Factors }\end{array}$ & & & & \\
\hline Social Capital & $\rightarrow$ & $\begin{array}{l}\text { Predisposing } \\
\text { Factors }\end{array}$ & 0.3260 & 0.0847 & 3.8491 & $\begin{array}{l}\text { Valid and } \\
\text { significant }\end{array}$ \\
\hline $\begin{array}{l}\text { Reinforcing } \\
\text { Factors }\end{array}$ & $\rightarrow$ & $\begin{array}{l}\text { Predisposing } \\
\text { Factors }\end{array}$ & 0.4205 & 0.1468 & 2.8647 & $\begin{array}{l}\text { Valid and } \\
\text { significant }\end{array}$ \\
\hline $\begin{array}{l}\text { Reinforcing } \\
\text { Factors }\end{array}$ & $\rightarrow$ & Behavior & 0.7011 & 0.1038 & 6.7521 & $\begin{array}{l}\text { Valid and } \\
\text { significant }\end{array}$ \\
\hline $\begin{array}{l}\text { Predisposing } \\
\text { Factors }\end{array}$ & $\rightarrow$ & Behavior & 0.4009 & 0.0506 & 7.9291 & $\begin{array}{l}\text { Valid and } \\
\text { significant }\end{array}$ \\
\hline
\end{tabular}




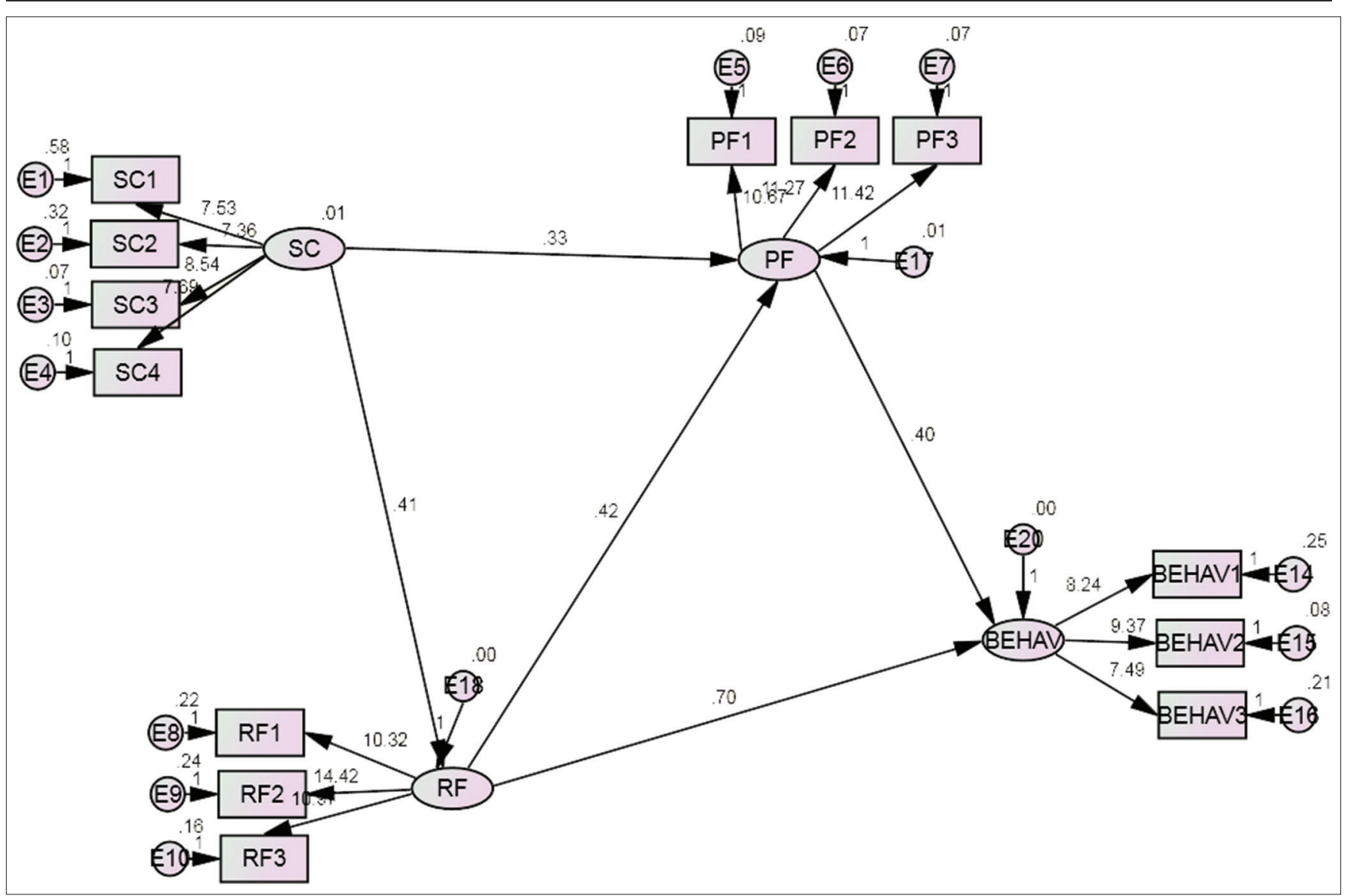

Figure 1: The final models of structural equation modeling

Table 2: The results of paired samples t-test (Intervention group)

\begin{tabular}{llllll}
\hline $\begin{array}{l}\text { Differences in the behavioral } \\
\text { variables of mothers visit posyandu }\end{array}$ & $\mathrm{n}$ & Mean & $\begin{array}{l}\text { Pre-post } \\
\text { difference }\end{array}$ & $\begin{array}{l}\text { Std. } \\
\text { Deviation }\end{array}$ & $\begin{array}{l}\text { Sig. } \\
\text { (2-tailed) }\end{array}$ \\
\hline Pre immediate intervention & 50 & 2.70 & 1.26 & 0.735 & 0.000 \\
Post immediate intervention & 50 & 3.96 & & 0.781 & \\
Pre regular intervention & 50 & 2.28 & 0.74 & 0.607 & 0.000 \\
Post regular intervention & 50 & 3.02 & & 0.589 & \\
Pre sustainability intervention & 50 & 2.24 & 0.84 & 0.894 & 0.000 \\
Post sustainability intervention & 50 & 3.08 & & 0.853 & \\
Pre total intervention & 50 & 7.22 & 2.78 & 0.996 & 0.000 \\
Post total intervention & 50 & 10.00 & & 1.212 & \\
\hline
\end{tabular}

From Table 1 found 5 valid and significant relationships including social capital affecting reinforcing factors, reinforcing factors influencing predisposing factors, reinforcing factors affecting behavior and predisposing factors affect behavior. To analyze the mean difference and standard deviation before and after intervention was done statistical analysis using paired-sample $t$-test (the intervention group was higher than control, $p=0.000$ ). Table 2 shows the results of

Table 3: The results of paired samples t-test (Control group)

\begin{tabular}{llllll}
\hline $\begin{array}{l}\text { Differences in the behavioral } \\
\text { variables of mothers visit posyandu }\end{array}$ & $\mathrm{n}$ & Mean & $\begin{array}{l}\text { Pre-post } \\
\text { difference }\end{array}$ & $\begin{array}{l}\text { Std. } \\
\text { Deviation }\end{array}$ & $\begin{array}{l}\text { Sig. } \\
\text { (2-tailed) }\end{array}$ \\
\hline Pre immediate control & 50 & 1.98 & 0.66 & 0.589 & 0.000 \\
Post immediate control & 50 & 2.64 & & 0.563 & \\
Pre regular control & 50 & 1.90 & 0.44 & 0.463 & 0.000 \\
Post regular control & 50 & 2.34 & & 0.593 & \\
Pre sustainability control & 50 & 2.06 & 0.46 & 0.767 & 0.000 \\
Post sustainability control & 50 & 2.52 & & 0.614 & \\
Pre total control & 50 & 5.92 & 1.70 & 0.778 & 0.000 \\
Post total control & 50 & 7.62 & & 1.048 & \\
\hline The final model recommended for improving the behavior of mothers visit posyandu.
\end{tabular}

the paired sample t-test of the intervention group of differences in behavior. The variables of mother's visit to posyandu are Pre immediate intervention, Pre regular intervention, Pre sustainability intervention, Pre total intervention.

Table 3 shows the results of the paired sample t-test of the control group of differences in behavior. The variables of mother's visit to posyandu are Pre immediate, Pre regular control, Pre sustainability control, Pre total control.

Figure 2, the last modeling, shows that the behavior of mothers visiting posyandu is influenced by Social Capital, Reinforcing Factors, Predisposing factors.

\section{Discussion}

Social capital factor can be known the highest mean is partnership, reciprocity, and participation. In predisposing factors, the highest mean is knowledge and motivation. From the analysis of Structural Equation Model, the result of social capital has an effect on the predisposing factors on the model of mother behavior to visit Integrated service post.

The basic elements of social capital: (1) Participation; In a Network one of the keys to the 


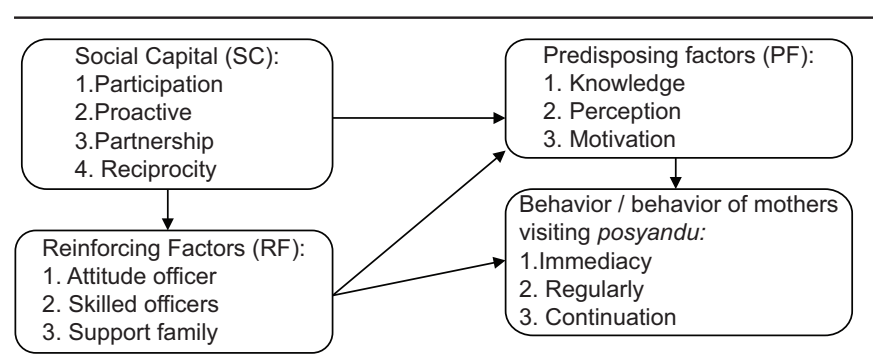

Figure 2: The final model recommended for improving the behavior of mothers visit posyandu

success of building Social Capital lies also in the ability of a group of people in an association or association in involving themselves in a network of social relations. The community is always social with other societies through various variations of mutual coexistence and is done on voluntary, equality, freedom, and civility principles. The ability of members of groups/ communities to always unite themselves in a pattern of relationship that will be very synergetic influence in determining whether or not a social capital group. (2) Resiprocity; social capital is always colored by the tendency of mutual exchange among individuals within a group or between groups themselves [8]. This pattern of exchange is not something that is done reciprocally as instantly as in the process of buying and selling, but rather a combination of short and long term in the nuances of altruism (the spirit to help and emphasize the interests of others). In the Islamic concept, this kind of spirit is called sincerity. The spirit to help for the benefit of others. The remuneration is not expected immediately and indefinitely. In societies, and in the social groups formed, which have strong reciprocity weights will give birth to a society that has another level of profit, the community will more easily build themselves, the group and their social and physical environments astonishingly. (3) Feelings of Trust and Safety; is a desire to take risks in social relationships based on feelings that others will do as expected and will always act in a mutually supportive pattern of action, at least. others will not act to the detriment of themselves and their group [9]. Research the relationship between social capital and community development as well as in community development explained that the contribution of social capital to economic development within the framework of socio-economic development. The results of this project show that social enterprises generate social capital in their areas largely by using social capital. Explicitly, shared values create solidarity between social companies such as minded, trust, and reciprocal builds in collaboration and collaboration. An active informal and formal network is built upon, which is likely to develop a social enterprise [10].

The elements of social capital can be described as follows: (a) Social networks, voluntary private networks; (b) Civic engagement and participation and use of civil networks; (c) Identity of local citizenship (citizen power), sense of belonging, solidarity, and equality with members of community groups, (d)
Reciprocity and co-operative values, the sense of duty to help others and be confident while accompanying, (e) and trust in the community [11].

Attitude is a form of evaluation or reaction of feelings whereas a person's attitude towards an object is a favorable or favorable feeling or an unfavorable feeling to the object. Attitude is a reaction or response that is still closed from someone to a stimulus. Attitude is a view or feeling that is accompanied by a tendency to act in accordance with the attitude of the object. So attitude is always directed towards a thing, an object, no attitude without object. Humans can have attitudes toward a variety of things. Attitude clearly shows the connotation of the corresponding reaction to a particular stimulus which in everyday life is an emotional reaction to social stimulus [3]. Attitude is not yet an action or activity, but it is a predisposition to the action of a behavior. It is still a closed reaction, not an open reaction or an open behavior. Attitude is a readiness to react to objects in a particular environment as an appreciation of an object. Practice or action: An attitude is not necessarily automatically manifested in the form of action (overt behavior). For the realization of the attitude to be a real action in need of supporting factors or a condition that allows, among other facilities. The level of practice are: (a) Perception; (b) Guided response (guided Response); (c) Mechanism (mechanism); (d) Adaptation [10].

In general, findings suggest that social capital (social trust, institutional trust, and social participation) are significantly positively influencing technological factors (perceived ease of use and perceived benefit), which affect intentions of use. This study also confirms that the self-efficacy system is important from the perception of ease of use. The proposed psychosocialtechnology integrative model can serve as a theoretical foundation for future research and may also offer an empirical outlook for practitioners and researchers in government health departments, hospitals, and rural communities. The results also show that the social capital performance link depends on the age of the small companies, the industries and the institutional context in which they operate, and on the network or performance of the specific measures used. Based on these findings, we developed recommendations for future research on the value of contingent social capital for small firms [11]. In predisposing factors, the highest mean is knowledge dan motivation. In the reinforcing factors factor, it can be known that the highest mean is family support and skilled officers. From the analysis of the Structural Equation Model, the result of reinforcing factors influenced predisposing factors in the model of mother behavior to visit posyandu.

Knowledge is the result of know and this happens after people do the sensing of a particular object. Knowledge or cognitive is a very important domain for the formation of one's actions. Behavior based on knowledge will be more lasting than not 
based on knowledge. Knowledge covered in the cognitive domain has 6 levels, namely: (a) Know (b) Comprehension (c) Application; (d) Analysis, (e) Synthesis and (f) Evaluation [12].

Motivation is a process that explains the intensity, direction, and persistence of effort to achieve a goal. Motivation is a process of influencing or encouraging from the outside of a person or working group so that they want to carry out something that has been determined. Motivation can also be interpreted as a driving force intended as a natural urge to satisfy and sustain life. Motivation is a change of energy in a person that is characterized by the emergence of feelings and reactions to achieve goals. Motivation is a process to activate motives into actions/behavior to meet the needs and achieve goals/conditions and readiness in individuals who encourage his behavior to do something in achieving goals. Motivation is a hidden force within us that encourages us to behave and act in a unique way. Motivation is the effort to provide conditions so that the child will do something [13].

Family support is verbal information, targets, real assistance, or behavior given by people who are familiar with the subject in their social environment or in the form of attendance and things that can provide an emotional advantage or influence on the behavior of acceptance. In this case a person who feels social support is emotionally relieved to be noticed, gets a favorable suggestion or impression on himself. Family support is an objection, sadness, concern from reliable people, respecting and caring for us. Family support is comfort, attention, appreciation, or helping people with acceptance of their conditions, family support are obtained from individuals or groups.

In the reinforcing factors factor, it can be known that the highest mean is family support and skilled officers. In the behavior factor, it can be known that the highest mean is sustainability and immediacy. From the analysis of Structural Equation Model, the result of reinforcing factors influences the behavior of behavioral model of mother to visit posyandu.

Family support is being comfortable, caring, rewarding, or helping people with acceptance of his condition, that family support is gained from individuals and groups. Forms of family support vary, among others (a) Emotional Support: The family as a safe and peaceful place to rest and restore and help mastery over emotions. Includes empathy expression, concern, and concern for family members suffering from leprosy (e.g. feedback, affirmation); (b) Appreciation Support: The family acts as a guidance for feedback, guiding and mediating problem-solving and as a source and validator of member identity. Occurs through positive expressions of respect for lepers, consent with individual ideas or feelings, and positive comparison of lepers with other sufferers such as those who are less able or worse (increase in self-esteem); (c) Tangible Assistance: The family is a source of practical and concrete help, including direct assistance such as money, equipment, time, environmental modification and help with stressful time work; (d) Information support: The family serves as a colletor and dessiminator (spreader) of information about the world, including advice, advice, advice or feedback. Forms of family support provided by the family are encouragement, giving advice, or supervising about the daily diet and treatment. Family support is also an individual feeling that gets noticed, liked, appreciated, and belongs to the community [10].

In enabling factors factor, it can be known that the highest mean is location/distance and facilities/ infrastructure. In the reinforcing factors factor, it can be known that the highest mean is family support and skilled officers. Enabling factors have no effect on reinforcing factors on behavioral models of mothers visiting posyandu [10].

Implementing posyandu activities is a priority of community members who have been trained to be local cadres under the guidance of health center. Posyandu management: is the board established by the head of real-world (RW) from the health care in the area. While the tasks of posyandu cadres are: (1) Preparing the target of posyandu; (2) Prepare the necessary tools and materials. If any tool that is not yet available can borrow, ask the health worker or make it yourself; and (3) the division of tasks among the cadres [14].

Attitude is a form of evaluation or reaction of feelings whereas a person's attitude towards an object is a favorable or unfavorable feeling to the object. Attitude is a reaction or response that is still closed from someone to a stimulus or object. Attitude is a view or feeling that is accompanied by a tendency to act in accordance with the attitude of the object. So attitude is always directed towards a thing, an object, no attitude without object. Humans can have attitudes toward a variety of things. Attitudes clearly show the connotation of the suitability of reactions to certain stimuli that in everyday life is an emotional reaction to social stimulus. Practice is an attitude that does not necessarily automatically manifested in the form of action (overt behavior). For the realization of the attitude to be a real action in need of supporting factors or a condition that allows, among other facilities. The level of practice are: (a) Perception; (b) Guided response; (c) Mechanism; (d) Adaptation [10].

Implementing posyandu activities is a priority of community members who have been trained to be local cadres under the guidance of health center. Posyandu management: Is the board established by the head of RW from the health cadre in the area. While the tasks of posyandu cadres are: (1) Preparing the target of posyandu; (2) Prepare the necessary tools and materials. If any tool that is not yet available can borrow, ask the health worker or make it yourself; and (3) Make the division of tasks among the cadres [9].

Perception is the process of organizing and interpreting the stimulus by organisms or individuals to 
obtain something meaningful and an integrated activity within the individual. Perception is the interpretation of what the individual senses or feels. Perception is a process of recognition and the process of giving meaning to the environment by individuals. Perception also includes the context of social life, so it is recognized social perception. Social perception is a process that occurs in a person who aims to know, interpret, and evaluate other people perceived, either about the nature, quality, or other circumstances that exist in the perceived person to form a picture of others as objects of perception. Perception is a process of giving meaning to the environment by an individual. Perception is a process that starts from the vision to form a response that occurs within the individual so that the individual is aware of everything in the environment through the senses he has. Humans as social beings as well as individual beings, then there are differences between individuals with one another [12].

The distance between houses with posyandu can also affect the presence of children under 5 years old, from the previous research that the respondents of the posyandu, especially mentioned because of the location of posyandu. Supporting facilities that are carried out are influenced by supporting facilities including referrals health center and hospital that always ready to receive toddlers who are subject to nutritional problems such as malnutrition, where in the activity directly carried out intensive handling [9].

Behavior is a response or a person's reaction to stimulus. Other theories that define the definition of behavior mean that the actions or activities of humans that have a very wide range include: walking, talking, crying, laughing, work, college, writing, reading, and so forth. Thus it can be concluded also that the behavior is all activities or activities of human, whether observed directly or can not be observed by outsiders.

Based on the results, the mean increase in group that given intervention bigger compared to control group. There was a difference of visit of the mother to the posyandu between the group who were given intervention and the control group. Thus there was a difference in the behavior of mother to visit posyandu between intervention group and control group [3].

\section{Conclusion}

Behavioral model of precede proceed and social capital have an effect on to increase of mother toddler's behavior to visit posyandu in Magetan Regency. The biggest paths that can improve the behavior of mothers to visit posyandu are reinforcing factors (attitudes of officers, skilled officers, and family support) to the behavior of mothers visiting posyandu. Therefore, to improve the behavior of mothers to visit posyandu, it requires a positive attitude of officers, adequate skills of the officers, and family support on the behavior of mothers to visit posyandu.

\section{Ethical Clearance}

Ethical permission is approval from the Health Polytechnic Research Ethics Commission of the Ministry of Health of Surabaya, this research does not use human and animal experiment objects.

\section{References}

1. Magetan Health Office. Health Profile of Magetan Regency in 2017. Magetan: Magetan Health Office; 2017.

2. MoH-RI. Main Results of Basic Health Research. Main Results of Basic Health Research (Hasil Utama Riset Kesehatan Dasar). Jakarta: Ministry of Health of the Republic of Indonesia; 2018.

3. Suharto A, Soedirham O, Dyson L. The Influence of Factors in Social Capital on the Behavior of Mothers to Visiting "Posyandu" Park, Dama International Journal of Researchers; 2016. p. 878.

4. Nursalam N. Research Methodology (Metodologi Penelitian). Jakarta: Salemba Medika; 2016.

5. Enander RT, Gagnon RN, Hanumara C, Park E, Armstrong T, Gute DM.Environmental health practice: statistically based performance measurement. Am J Public Health. 2007;97(5):819-24.

6. Nursalam N. Concept and Application Research Methodology in Nursing Science (Konsep dan Penerapan Metodologi Penelitian IImu Keperawatan). Jakarta: Salemba Medika; 2014.

7. Machali I. Statistics are Easy, Using SPSS as a Statistical Tool (Statistik Itu Mudah, Menggunakan SPSS Sebagai Alat Bantu Statistik); 2015. p. 214.

8. Moretti LS, Candini V, Cárdenas F, Conn H, Fabbro F, Muñoz-Navarro R, et al. An appraisal of the fit of a cognitive behavioural model of headache in University students. J Behav Health Soc Issues. 2017;9(2):54-61.

9. Suharto A, Surtinah N, Rahayu TP. Cadre Behavior Mode Independence to Improve the Early Detection of Children Growth and Development in the Posyandu Park District Magetan East Java of Indonesia, Magetan; 2016.

10. WHO. Statements from Global Conferences. Geneva: WHO; 2017.

11. Maqsood M, Maqsood $H$, Kousar $R$, Jabeen $C$, Waqas $A$, Gillani SA, et al. Effects of hospital service quality on patients satisfaction and behavioural intention of doctors and nurses. Saudi J Med Pharm Sci. 2017;3(6B):556-67.

12. Salehi A, Jannati A, Nosratnjad S, Heydari L. Factors influencing the inpatients satisfaction in public hospitals: A systematic review. Bali Med J. 2018;7(1):17-26.

13. Fatima T, Malik SA, Shabbir A. Hospital healthcare service quality, patient satisfaction and loyalty: An investigation in context of private healthcare systems. Int J Qual Reliab Manag. 2018;35:1195-214.

14. Saepuddin E, Rizal E, Rusmana A. Posyandu roles as mothers and child health information center. Rec Libr J. 2018;3(2):201. 